\title{
New Media and Political Revival: The Middle East Story
}

\section{Rana Hassan*}

Mass Communication Department, Qatar University, Doha, Qatar

There are decades where nothing happens; and there are weeks where decades happen"

\section{(Vladimir Ilyich Lenin).}

It has become evident that the Arab revolutions that took place in Tunisia, Egypt and Libya have marked a turning point in Arab politics. On the other side, it was also a turning point of realizing the importance of social media and citizen journalism. All of these historical changes have been powered by citizens participation and the more participation, the better the communication [1].

The Arab spring has taken place in Middle Eastern countries and is shaping the history of the region after many years of oppression by the various regimes. It all started with the Tunisian revolution where Tunisians took real action after 23 years of regime domination. Local media was biased towards governments and prevented the truth from appearing which resulted in political and social ignorance. Social media networks such as Facebook and twitter were introduced to people as a source of socializing and entertainment at the beginning then other usages were explored.

Arab activists have been thrilled with the experience of Facebook as a source of socialization and friending. Starting to sign up for accounts, members have been on the increase day by day. Different activities were practiced especially political ones. Due to the tragic incidences that happened within different regimes in most of the countries, social media networks succeeded in at least bringing disengaged and uninvolved youth to the attention of the media and in shaping public opinion [2].

Paul Bleicher [3] described the internet as a multidirectional information source such as webpages but with the introduction of "web 2.0" a larger, interactive platform has been introduced to public in a collaborative manner such as Wikipedia. Such change resulted on Cyber activism which refers to promoting political and social causes that can be shifted from normalization to mobilization and encourage people to act physically and feel the power of change.

Sahar Khamis [4] stated that new media had various roles during the Egyptian revolution: a major call for street and physical participation, enabling cyber activism, encouraging people to participate in civic activities and promoting citizen journalism. Some activists stated that the revolution idea was in their minds before January 25th and that explains several protests that took place in 2010. But in the January 25th revolution, the strategy was different; using social media to publicize and create propaganda to ensure popularity and more participants. The call for political change was partly driven by popular Facebook groups which included street and physical activism in addition to cyber activism: The National Coalition for Change- which is known as Mohamed Al-Baradee, April 6th Movement and We are all Khalid Saeed.

New Media has opened a gate for citizen Journalism. Everything that the mainstream media doesn't mention, social media does and documents everything. The role of new media haven't stopped after defeating the old regimes, It is a continuous role that takes place in each country. In Egypt, it is known as social media war; most of the people shifted their interests from socialization to political participation. Some people are posting pictures and videos of the current regime mistakes and corruption trying to find out solutions and calling for a rebellion by signing an application to end Mohamed Morsi's and Muslim brotherhood regime named as 'rebel' movement. On the other hand, Salafies and Muslim brotherhood groups are fighting against liberal movements and also posting videos and pictures of any mistake they can find. Social media became the weapon that people use to fight, answer back, organize civic movements and many other political activities. Before introducing social media, people were totally dependent on mainstream media, as they didn't have any other source of information. Nowadays, mainstream media is depending on social media material to make news and change public opinion. Therefore, one can say that this is the new media era that changed and will keep on changing history not only in the Middle East but in the whole world.

\section{References}

1. Russell A (2011) Extra-National Information Flows, Social Media and the 2011 Egyptian Uprising. International Journal of Communication 1238-1247.

2. Miladi N (2012) New media and the Arab revolution: citizen reporters and social activism. Journal of Arab and Muslim Media Research 4: 3-5.

3. Bleicher P (2006) Web 2.0 revolution: power to the people. Applied Clinical Trial Magazine 15: 34-36.

4. Khamis S (2011) The Transformative Egyptian Media Landscape: Changes, Challenges and Comparative Perspectives. International Journal of Communication 5: 1159-1177.

*Corresponding author: Rana Hassan, Mass Communication Department, Qatar University, Doha, Qatar, Tel: 4403-4877; E-mail: rana.hassan@qu.edu.qa

Received May 21, 2013; Accepted May 23, 2013; Published May 24, 2013

Citation: Hassan R (2013) New Media and Political Revival: The Middle East Story. J Mass Communicat Journalism 3: e135. doi:10.4172/2165-7912.1000e135

Copyright: ( $) 2013$ Hassan R. This is an open-access article distributed under the terms of the Creative Commons Attribution License, which permits unrestricted use, distribution, and reproduction in any medium, provided the original author and source are credited. 